Therefore one would expect that significant variations in the labelling index of bone marrow blast cells would be reflected by the labelling index in the blood. It is likely, then, that the lack of diurnal variation in the labelling index applies to all leukaemic blast cells irrespective of where they are located.

This investigation was supported by a research grant $(C A$ 5492) from the National Cancer Institute, U.S. Public Health Service.

K. Rour

S. Å. KrLtmanN

Rigshospitalet,

University Hospital of Copenhagen, Denmark.

${ }^{1}$ Golobova, M. T., Bull. Exp. Biol. and Med. (English translation) 46, 1143 (1958).

${ }^{2}$ Bertalanffy, F. D., Acla Anat., 40, 130 (1960).

${ }^{3}$ Bullough, W. S., and Laurence, E. B., Proc. Roy. Soc., B, 154, 540 (1961).

- Pilgrim, C., Erb, W., and Maurer, W., Nature, 199, 863 (1963).

${ }^{5}$ Voutilainen, A., Acta Pathol. Microbiol. Scand., Supp. 99, 1 (1953).

6 Bertalanffy, F. D., Nature, 198, 496 (1963).

7 Frenkel, E. P., Korst, D. R., and Zarafonetis, C. J. D., presented at the ninth Internat. Congress Haematol., Mexico City, Sept., 1962.

${ }^{8}$ Killmann, S. A.., Cronkite, E. P., Fliedner, T. M., Bond, V. P., and Robertson, J. S., Lab. Invest., 12, 671 (1963).

' Killmann, S. A., Proc. 70, Tagung deutsch. Ges. inn. Medizin, Wiesbaden,

${ }^{10}$ Killmann, S. A. (unpublished work).

\section{Pathological Excretion of 4-Hydroxy-3-methoxyphenyllactic Acid}

ONE of the 'spots' frequontly appearing on paper chromatograms of the phenolic acids in human urine has been examined in these laboratories for some six years, since it was recognized as being of complex nature. Normally it appears to consist of a mixture of 4-hydroxy3-methoxy- and 3-hydroxy-4-methoxyphenylhydracrylic acids, both probably largely derived from dietary chlorogenic acid, the latter isomer sometimes being observed in relatively large amounts following the consumption of citrus fruits containing the flavonoid hesperidin ${ }^{1}$. However, at least two other strongly acidic substances having rather similar $R_{F}$ values have occasionally been detected, particularly in extracts prepared from urines which have been refluxed with acid in order to destroy the hydracrylic acids. The chromatographic properties of these compounds are recorded in Table 1.

Table 1. Chromatographic Properties of 3 Phenolic Acids

\begin{tabular}{|c|c|c|c|}
\hline & $\begin{array}{l}\text { 3-Hydroxy-4- } \\
\text { methoxyphenyl- } \\
\text { hydracrylic } \\
\text { acid }\end{array}$ & $\underset{A}{\text { Compound }}$ & $\begin{array}{l}\text { Compound } B \\
\text { (4-hydroxy-3- } \\
\text { methoxyphenyl } \\
\text { lactie acid) }\end{array}$ \\
\hline $\begin{array}{l}R_{F} \text { in anisole-acetic acid- } \\
\text { water }(70: 29: 1)\end{array}$ & $0 \cdot 34$ & 0.33 & $0 \cdot 34$ \\
\hline $\begin{array}{l}\text { actd-water (125:72:3) } \\
R_{F} \text { in dioxan-methyl isobutyl }\end{array}$ & $0 \cdot 15$ & 0.12 & $0 \cdot 14$ \\
\hline $\begin{array}{l}\text { ketone-pyridine-water } \\
(40: 40: 12: 20) \\
R \text { in isopropanol-ammonla- }\end{array}$ & 0.44 & $0 \cdot 30$ & $0 \cdot 32$ \\
\hline $\begin{array}{l}\text { water }(8: 1: 1) \\
\text { Colour with diazotized }\end{array}$ & 0.31 & 0.35 & $0 \cdot 35$ \\
\hline $\begin{array}{l}p \text {-nitroaniline } \\
\text { Colour with diazotized }\end{array}$ & Violet-blue & Blue & Grey \\
\hline $\begin{array}{l}\text { sulphanilic acid } \\
\text { Colour with } 2: 6 \text {-dichloro- }\end{array}$ & Red-orange & Violet-red & Violet-red \\
\hline quinone chloroimide-borax & Blue & Blue & Negligible \\
\hline
\end{tabular}

Compound $A$ was investigated in a case of neuroblastoma in which it was excreted in relatively large quantity. A similar spot has been detected in only one other subject, a case of post-operative stress maintained on a noradrenaline drip. The possibility that the sub. stance is a drug metabolite cannot be excludod.

Compound $B$ was particularly prominent in the case of malignant phaeochromocytoma previously reported ${ }^{2}$. Its chromatographic properties are identical with those of 4-hydroxy-3-methoxyphenyllactic acid, itself conveniently isolated as its sodium salt after reduction of 4-hydroxy-3-methoxyphenylpyruvic acid in aqueous ethanol with sodium borohydride. The acid was detected, in small amount, in only one other of 30 phaeochromocytoma urines examined. However, this metabolite of 3:4-dihydroxyphenylalanine was also detected readily in one case of neuroblastoma and small amounts appeared to be excreted in 5 of 10 further cases of this condition (cf. ref. 3).

A variety of pathological urines have been examined for the presence of 4-hydroxy-3-methoxyphenyllactic acid, using diazotized $p$-nitroaniline for its detection after paper chromatography ${ }^{4}$ of extracts of acid hydrolysed urines equivalent to $1 \mathrm{~min}$ excretion or to $1 \mathrm{mg}$ of creatinine excreted. The acid was thus detected in 2 cases of cancer, one of gross kidney deficiency and one of rheumatoid arthritis in a total of 72 subjects. The foregoing urines were selected, usually because abnormalities in phenolic acid excretion were revealed, from a much larger series which were examined without recourse to acid treatment; many such urines did not contain interfering hydracrylic acids, but in none of these was the lactic acid detected. It has not yet been encountered in any normal urine or in urines from subjects under stress. Nevertheless its presence in traces in all urines may be inferred since the closely related 4-hydroxy-3-methoxyphonylpyruvic acid appears to be invariably present in small quantity, detectable as the derived hydantoin formed by condensation with urea under acid conditions. However, excretion of the lactic acid in readily detectable amount seems to be a very uncommon phenomenon which is particularly, if not invariably, associated with the abnormal production of 3 :4-dihydroxyphenylalanine; it also appears to be usually associated with high excretion of $p$-hydroxyphenyllactic acid.

Allowance for possible confusion with compound $A$ should be made if 4-hydroxy-3-methoxyphenyllactic acid is to be detected on paper chromatograms with diazonium reagents only. In particular, the grey colour obtained with diazotized $p$-nitroaniline (Table 1 ) may be distinctly blue if the coupling is not carried out under alkaline conditions. Compounds identified as the lactic acid have been reported to yield 'blue-violet's or 'light blue's colours by other workers.

\section{P. Sмiтн}

Royal Air Force Institute of Aviation Medicine, Farnborough, Hants.

Robinson, R., Ratcliffe, J., and Smith, P., J. Clin. Path., 12, 541 (1959) ${ }^{2}$ Smith, P., in The Clinical Chemistry of Monoamines (Elsevier, 1963). ${ }^{3}$ Gjessing, L. R., Scand. J. Clin. Lab. Invest., 15, 649 (1963).

Hill, G. A., Ratcliffe, J., and Smith, P., Chem. and Indust., 399 (1959). Choremis, K. B., Constantsas, N., and Danelatos-Athanassiadis, K., Clin.
Chim. Acta, 8, 814 (1963).

\section{Enhancing Effect of Thymectomy on Hepatotumorigenesis in Swiss Mice following Neonatal Injection of 20-Methylcholanthrene}

UNTIL recently, liver has proved refractory to tumour induction by carcinogenic hydrocarbons. Klein ${ }^{x}$ reported in 1959 that the increased incidence of liver tumour was attained by initiating repeated oral administration of 3 -methylcholanthrene in suckling mice 7-9 days of age. Kelly and O'Gara also noted that liver tumours were found in 6 of 11 male $\mathrm{C} 3 H$ mice after a single subcutaneous injection of 3-methylcholanthrene at birth.

Many tumours induced by chemical carcinogens are antigenic in the syngeneic and even autochthonous hosts ${ }^{3,4}$. This led to the concept, as noted by Miller et al. ${ }^{5}$, that "tumour progression might be possible only when the host's mechanism for homograft immunity is eithor poorly developed or depressed as a result of irradiation or of the chemical carcinogen itself". Depression of immune 